\title{
Five slices through the Nuussuaq Basin,West Greenland
}

\author{
Asger Ken Pedersen, Lotte Melchior Larsen, Gunver Krarup Pedersen and Keld S. Dueholm
}

In 2006 an important milestone will be reached in the study of the three-dimensional structure and architecture of the Nuussuaq Basin in West Greenland. The fifth and last of a series of detailed geological profiles through the sedimentary and volcanic rocks of the Nuussuaq Basin on Disko and Nuussuaq will be published (Fig. 1). At the same time, the last geological map at scale 1:100 000 of the basin area will be completed. These studies have been carried out over more than two decades by a group of scientists within Geocenter Copenhagen and the Technical University of Denmark.

The five geological profiles are at scale 1:20 000 and have been published as coloured plates in the same format as the geological maps (Pedersen et al. 1993, 2002a, 2003, 2005, 2006). In total, the profiles cover about $500 \mathrm{~km}$ of cross-sections through a classic sedimentary-volcanic basin and its crystalline basement. This is one of the best exposed basins of its kind on Earth, and it serves as a reference area for studies of similar basins on the continental shelves of Greenland, north-western Europe and elsewhere.

\section{The Nuussuaq Basin}

During the late Mesozoic, a series of linked sedimentary basins were established along the West Greenland continental margin. The Nuussuaq Basin is the only one of these basins that extends into the onshore areas where Late Cretaceous to Paleocene sediments overlain by volcanic rocks can be studied in detail. From the Late Albian, sandstones and shales were deposited in a fluvial to deltaic environment in eastern Disko and central Nuussuaq. Towards west and north the delta fanned into deeper water. Several tectonic phases affected the basin and gave rise to an uplifted rift margin of Precambrian gneiss in eastern Nuussuaq and a gneiss ridge in central Disko (Chalmers et al. 1999). In the Paleocene around $62 \mathrm{Ma}$ (Storey et al. 1998), volcanism started on the sea floor in the western part of the area. The volcanic pile rapidly became emergent and the lavas prograded eastwards into the marine embayment and gradually filled it with thick foreset-bedded hyaloclastites capped by subaerial lava flows. Thus, most of the early volcanic units exist in both subaerial and subaqueous facies. Eventually the marine basin, and also some slightly younger lake basins, was obliterated. The volcanic rocks interfingered with fluvial sandstones and lake

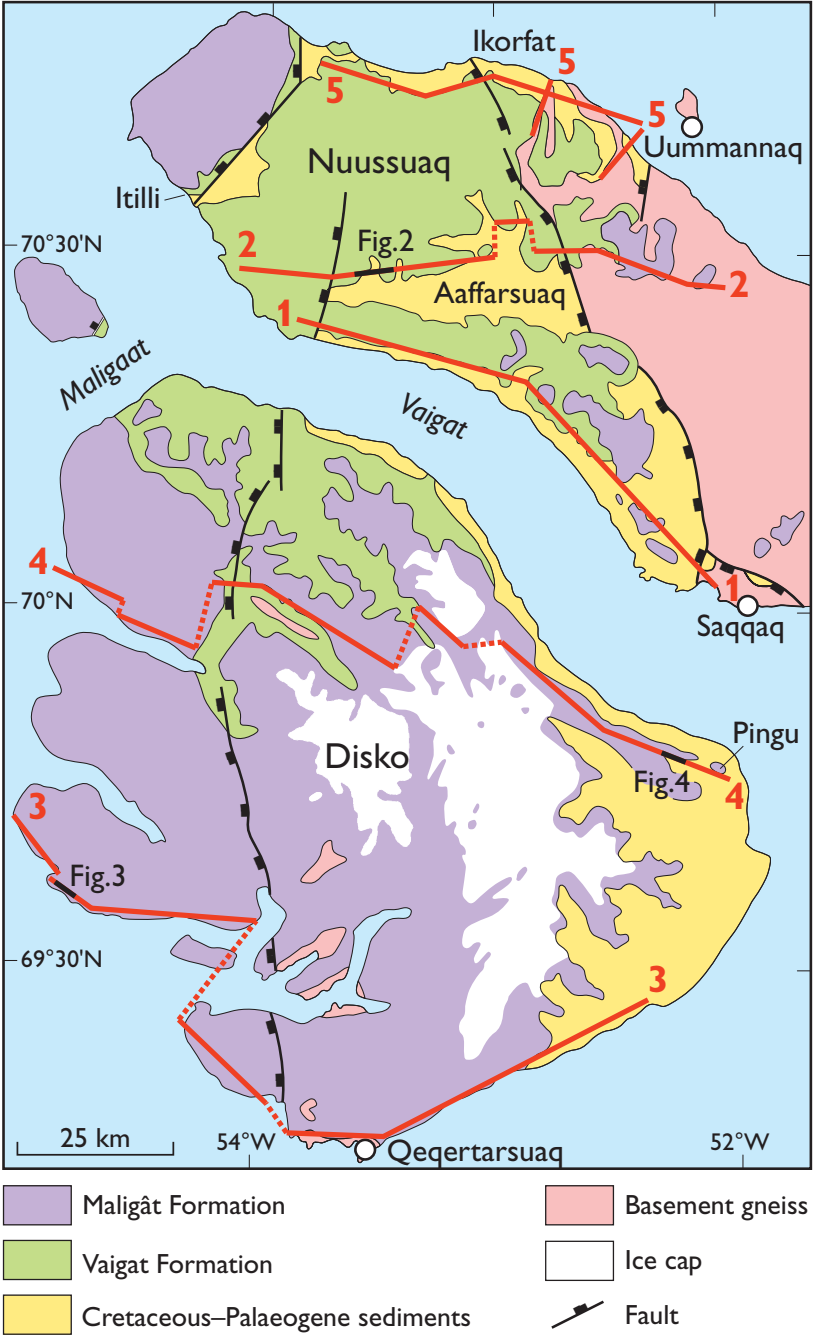

Fig. 1. Index map, with red lines showing the location of the five geological profiles through Disko and Nuussuaq. Profile 1: Pedersen et al. (1993); profile 2: Pedersen et al. (2002a); profile 3: Pedersen et al. (2003); profile 4: Pedersen et al. (2005); profile 5: Pedersen et al. (2006).

sediments in southern Nuussuaq and eastern Disko, whereas in eastern Nuussuaq they lapped onto the Precambrian highlands.

The volcanic rocks form two formations: the older Vaigat Formation of thin pahoehoe flows of magnesia-rich picrites and their equivalent hyaloclastites, and the overlying Maligât Formation of thick, extensive lava flows of basalt and their 


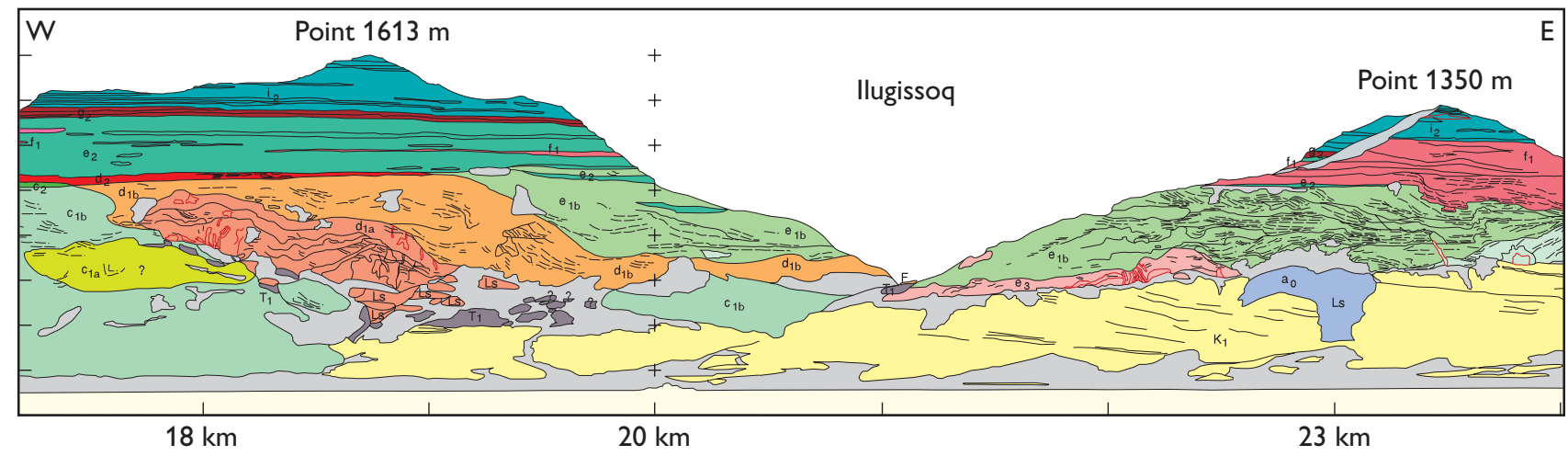

Fig. 2. Part of the geological section through the Aaffarsuaq valley (profile 2), central Nuussuaq (Pedersen et al. 2002a) at 17-24 km on the section base line. No vertical exaggeration. Sediments of the Cretaceous Atane Formation $\left(\mathrm{K}_{1}\right)$ and the Paleocene Eqalulik Formation $\left(\mathrm{T}_{1}\right)$ are overlain by several volcanic units of the Vaigat Formation. The Atane Formation was faulted and tilted prior to the deposition of the volcanic rocks, and a large fault crosses the profile at $18.5 \mathrm{~km}$ west of which the Atane Formation is below exposure level. During the deposition of the volcanic rocks, subaqueous hyaloclastite breccias and subaerial lava flows prograded into the basin from the west to the east. Lava flows and hyaloclastite breccias from the same volcanic unit are shown with respectively darker and lighter colour shades; such subaerial-subaqueous pairs are $\mathrm{c}_{2}$ and $\mathrm{c}_{1(\mathrm{a}+\mathrm{b})}$; $\mathrm{d}_{2}$ and $\mathrm{d}_{1(\mathrm{a}+\mathrm{b})}(\mathrm{Nuuk}$ Killeq Member), and $e_{2}$ and $e_{1(a+b)}$ (Naujánguit Member). The hyaloclastite breccias show east-dipping foreset bedding $\left(\mathrm{d}_{1 \mathrm{~b}}\right)$ or irregular bedding structures $\left(d_{1 a}, e_{1 b}\right)$ near eruption sites (feeder dykes lined with red). The red unit $\mathrm{f}_{1}$, at around 23-24 km, comprises the pyroclastic rocks of the Ilugissoq volcano (Asuk Member) which erupted on the margin of the shallow marine shelf. The younger units are banked up against the volcanic edifice, and the lavas of the unit $\mathrm{i}_{2}$ (Ordlingassoq Member) overran and covered it.

equivalent hyaloclastites. A detailed stratigraphy of the volcanic succession has been established based on lithology and geochemical analyses; several distinct units of crustally contaminated rocks form particularly good marker horizons because they are interbedded with the normal lithologies.

Oil seepages are found in the volcanic rocks in western Nuussuaq and northern Disko, and the Nuussuaq Basin is a key area in the exploration for oil both onshore and offshore West Greenland. Exploration for nickel and platinum has been focused on some of the contaminated volcanic units in which these elements are missing from the surface deposits and may have formed accumulations at depth in magma chambers.

\section{Methods}

Many mountain walls in the Nuussuaq Basin are excellently exposed but largely inaccessible. However, they can be photographed from boat or helicopter. The key data for the five geological profiles consists of long series of colour stereo photographs taken with ordinary, but calibrated, small-frame cameras. These photographs have been orientated and measured using multi-model photogrammetry as described by Dueholm (1992) and Pedersen \& Dueholm (1992). In combination with field logging, sampling, geochemistry and petrography, this has enabled us to establish a detailed stratigraphical framework for the volcanic rocks and hence to trace the evolution and facies changes of the volcanic and sedimentary units with time.

\section{The profiles}

The individual profiles (Fig. 1), at scale 1:20 000, are between $80 \mathrm{~km}$ and $131 \mathrm{~km}$ long and show altitudes up to $2100 \mathrm{~m}$ with no vertical exaggeration. Three examples illustrating aspects of the contents and details of the profiles are shown in Figs 2-4.

Figure 2 shows progradation of hyaloclastite breccias and associated lava flows into a marine basin; this structure, with giant foresets in the hyaloclastite breccias, has been widely used as a model for the interpretation of seismic sections in offshore areas. An unusual feature of central Nuussuaq is the presence of submarine feeder systems and eruption sites for several of the volcanic units, which make the bedding structures in the hyaloclastites very irregular. The concentration of feeder sites in this small area is due to the presence of a deep fault zone, along which magma ascent from the mantle was focused.

Figure 3 illustrates late tectonic movements and subsequent dyke intrusion. Near the west coast of Disko the lava pile is faulted and tilted seawards at low angles that can be read very accurately on the profile. The reading of the dips requires that the strikes are perpendicular to the section which is mostly, but not always, the case; the index maps accompanying each profile sheet show strikes and dips of the lavas along the profiles.

Figure 4 illustrates sediments and lava flows and their interaction on the flood plain in the eastern part of the basin in north-east Disko. Fluvial sandstones are interbedded with 


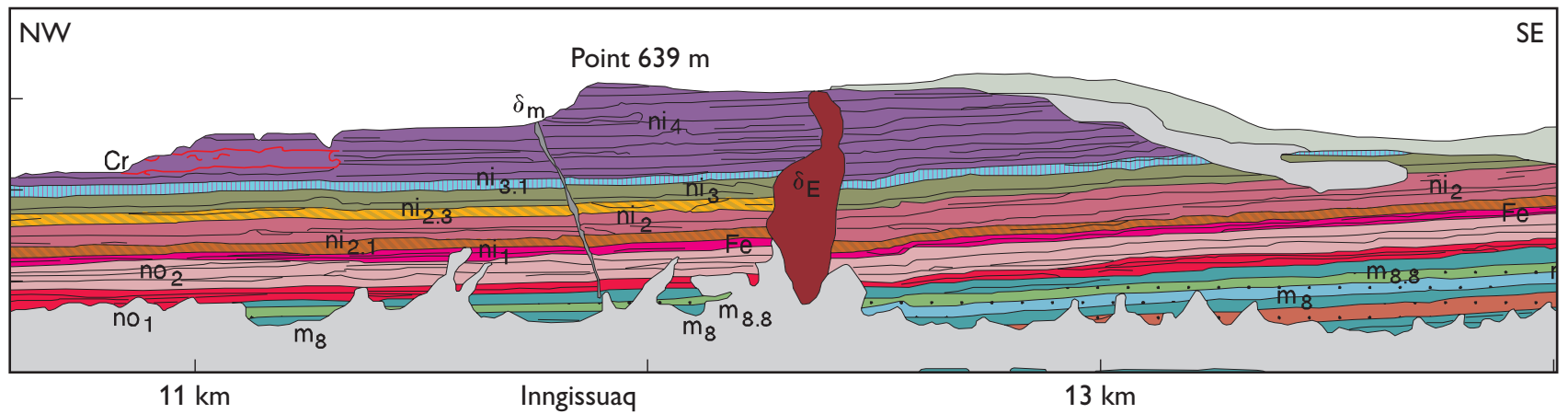

Fig. 3. Part of the geological section along the south-west coast of Disko (Pedersen et al. 2003) at 10.6-14 km on the section base line (profile 3). No vertical exaggeration. The pile of formerly flat-lying subaerial lava flows is tilted and the lavas dip $2^{\circ}-4^{\circ}$ seawards (to the left), preserving some of the stratigraphically highest lava flows of the Maligât Formation on the mountain tops. The unit $\mathrm{m}_{8.8}$ is the uppermost part of the Rinks Dal Member in which individual lava flows are indicated with separate colours and annotation (e.g. $\mathrm{m}_{8}$ ); such individual flows extend typically over 5 - 15 km and then

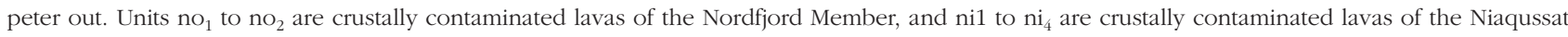
Member, of which $n_{1}$ carries native iron $(\mathrm{Fe})$. A crater area $(\mathrm{Cr})$ with thick, irregular, red-oxidised material is seen in the left part of ni ${ }_{4}$. The lava pile is cut by younger dykes $\left(\delta_{\mathrm{m}}\right.$ and $\delta_{\mathrm{E}}$ ) of which the Eocene $\delta \mathrm{E}$ runs very obliquely to the section.

two units of Paleocene black shales, both of which were deposited in large and deep lakes. The Paleocene sediments are contemporaneous with volcanic rocks in the western part of the basin; the first volcanic unit to reach so far east was the middle part of the Rinks Dal Member of the Maligât Formation.

The boundaries between the major volcanic units form important near-isochronous surfaces that allow the tracing of regional syn- and post-volcanic tectonic movements in the Nuussuaq Basin. For example, the boundary between the upper Rinks Dal Member and the Nordfjord Member of the Maligât Formation is tilted below sea level in western Disko (Fig. 3) and rises eastwards towards the Disko Gneiss Ridge to more than $1600 \mathrm{~m}$ altitude in central Disko. East of the gneiss ridge the surface is gently tilted towards the south-east by slow syn- and post-volcanic regional movements, so that in eastern Disko (Fig. 4) it is situated at $940 \mathrm{~m}$ altitude. In eastern Nuussuaq the same surface is situated at up to $1800 \mathrm{~m}$ altitude (not shown here).

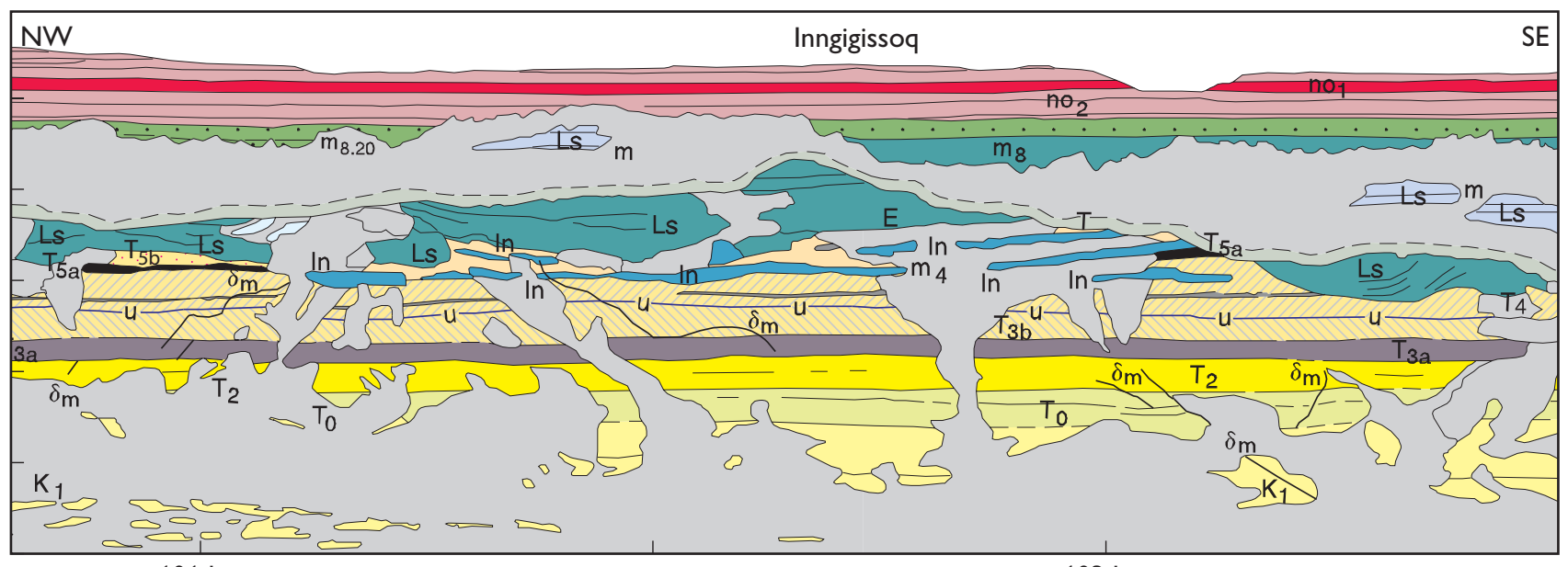

$101 \mathrm{~km}$

$103 \mathrm{~km}$

Fig. 4. Part of the geological section across Disko, near Pingu in eastern Disko (Pedersen et al. 2005) at 100.6-104 km on the section base line (profile 4). No vertical exaggeration. Sediments and lava flows are shown as viewed from the south, but are projected into the section both from the south (upper part) and from the north (lower part below the broken line: exposures along the Vaigat coast). Fluvial sandstones of Cretaceous ( $\mathrm{K}_{1}$ ) and Paleocene $\left(\mathrm{T}_{2}\right)$ age are separated by an interval of uncertain age $\left(\mathrm{T}_{0}\right)$. Two lake complexes each show filling with a coarsening-upwards succession of black mudstones and fluvial sandstones: the Pingu Member $\left(\mathrm{T}_{3 \mathrm{a}}-\mathrm{T}_{3 \mathrm{~b}}\right)$ and the Assoq Member $\left(\mathrm{T}_{5 \mathrm{a}}-\mathrm{T}_{5 \mathrm{~b}}\right)$. The level marked ' $\mathrm{u}$ ' is an unconformity within the sandstones. Lava flows invaded the unconsolidated sediments to form three sill-like bodies (invasive lavas, In), and finally the sediments were overrun by entirely subaerial lava flows. The entablature zone (E) of the lowest flow indicates a moist environment. The lava flows are from the Maligât Formation, upper Rinks Dal Member $\left(\mathrm{m}_{8}\right)$ and Nordfjord Member (iron-bearing $\mathrm{no}_{1}$, and $\mathrm{no}_{2}$ ). 


\section{Perspectives}

The completion of the five profiles, and the complementary geological maps at scale 1:100 000, has provided a significantly improved understanding of the overall three-dimensional structure and stratigraphy of the southern part of the Nuussuaq Basin, in particular of the well-exposed volcanic formations. In addition to the published profiles, an extensive web of colour stereo panels has been constructed wherever helicopter logistics allowed the photography, so that the total coverage now exceeds $1500 \mathrm{~km}$ of stereo panels. The existence of this web, assisted by complete on-line coverage of vertical aerial photograph models, has opened for a range of quantitative geological studies centred on volcanology, sedimentology, palaeomagnetics and tectonics. Using palaeomagnetic information, Pedersen et al. (2002b) calculated eruption rates and basin subsidence rates for an early part of the Vaigat Formation, and found eruption rates to be much in excess of those characterising modern Iceland. Measurements of lake depths and lateral correlation of subaqueous volcanic units over more than $20 \mathrm{~km}$ were instrumental for the understanding of the environment that gave rise to unique subaqueous rootless volcanic cones in the Assoq lake (Larsen et al. in press). The ability of the photogrammetrical method to identify volcanic eruption sites within the web of stereo panels has been demonstrated by the discovery of a large number of crater sites within the Vaigat Formation on Nuussuaq. Of particular significance is the observation that economically interesting crustally contaminated volcanic rocks tend to erupt along older fault zones within the basin. Such an example is provided by the Ilugissoq graphite andesite volcano (Pedersen \& Larsen in press), which is the largest eruption site within the Vaigat Formation. It is believed that continued 3-D based work within the Nuussuaq Basin will be of considerable interest for a broad range of geoscientists from both universities and industry.

\section{Acknowledgements}

The work was partly supported by the Carlsberg Foundation, grant no. 0385/30

\section{References}

Chalmers, J.A., Pulvertaft, T.C.R., Marcussen, C. \& Pedersen, A.K. 1999: New insight into the structure of the Nuussuaq Basin, central West Greenland. Marine and Petroleum Geology 16, 197-224.

Dueholm, K.S. 1992: Geological photogrammetry using standard smallframe cameras. In: Dueholm, K.S. \& Pedersen, A.K. (eds): Geological analysis and mapping using multi-model photogrammetry. Rapport Grønlands Geologiske Undersøgelse 156, 7-17.

Larsen, L.M., Pedersen, A.K. \& Pedersen, G.K. 2006: A subaqueous rootless cone field at Niuluut, Disko, Paleocene of West Greenland. Lithos 92, 20-32.

Pedersen, A.K. \& Dueholm, K.S. 1992: New methods for the geological analysis of Tertiary volcanic formations on Nuussuaq and Disko, central West Greenland, using multi-model photogrammetry. In: Dueholm, K.S. \& Pedersen, A.K. (eds): Geological analysis and mapping using multi-model photogrammetry. Rapport Grønlands geologiske Undersøgelse 156, 19-34.

Pedersen, A.K. \& Larsen, L.M. 2006: The Ilugissoq graphite andesite volcano, Nuussuaq, central West Greenland. Lithos 92, 1-19.

Pedersen, A.K., Larsen, L.M. \& Dueholm, K.S. 1993: Geological section along the south coast of Nuussuaq, central West Greenland. 1:20 000 coloured geological sheet. Copenhagen: Geological Survey of Greenland.

Pedersen, A.K., Larsen, L.M. \& Dueholm, K.S. 2002a: Geological section along the north side of the Aaffarsuaq valley and central Nuussuaq, central West Greenland. 1:20 000 coloured geological sheet. Copenhagen: Geological Survey of Denmark and Greenland.

Pedersen, A.K., Larsen, L.M., Riisager, P. \& Dueholm, K.S. 2002b: Rates of volcanic deposition, facies changes and movements in a dynamic basin: the Nuussuaq Basin, West Greenland, around the C27n-C26r transition. In: Jolley, D.W \& Bell, B.R. (eds): The North Atlantic Igneous Province: Stratigraphy, tectonics, volcanic and magmatic processes. Geological Society (London) Special Publications 197, 157-181.

Pedersen, A.K., Larsen, L.M., Pedersen, G.K., Heinesen, M.V. \& Dueholm, K.S. 2003: Geological section along the south and south-west coast of Disko, central West Greenland. 1:20 000 coloured geological sheet. Copenhagen: Geological Survey of Denmark and Greenland.

Pedersen, A.K., Larsen, L.M., Pedersen, G.K. \& Dueholm, K.S. 2005: Geological section across north central Disko from Nordfjord to Pingu, central West Greenland. 1:20 000 coloured geological sheet. Copenhagen: Geological Survey of Denmark and Greenland.

Pedersen, A.K., Larsen, L.M., Pedersen, G.K., Sønderholm, M., Midtgaard, H.H., Pulvertaft, T.C.R. \& Dueholm, K.S. 2006: Geological section falong the north coast of the Nuussuaq peninsula, central West Greenland. 1:20 000 coloured geological sheet. Copenhagen: Geological Survey of Denmark and Greenland.

Storey, M., Duncan, R.A., Pedersen, A.K., Larsen, L.M. \& Larsen, H.C. 1998: ${ }^{40} \mathrm{Ar} /{ }^{39} \mathrm{Ar}$ geochronology of the West Greenland Tertiary volcanic province. Earth and Planetary Science Letters 160, 568-586.

\footnotetext{
Authors' addresses

A.K.P., Geological Museum, University of Copenhagen, Øster Voldgade 5-7, DK-1350 Copenhagen K, Denmark. E-mail: akp@snm.ku.dk.

L.M.L., Geological Survey of Denmark and Greenland, Øster Voldgade 10, DK-1350 Copenhagen K, Denmark.

G.K.P., Geological Institute, University of Copenhagen, Øster Voldgade 10, DK-1350 Copenhagen K, Denmark.

K.S.D., Information and Mathematical Modelling, Richard Petersens Plads, DTU-Bygning 321, DK-2800 Lyngby, Denmark.
} 